\title{
Türkiye'de Tescil Edilmiş Bazı Makarnalık Buğday (Triticum durum L.) Çeşitlerinin Mardin - Kızıltepe Koşullarında Verim ve Kalite Özelliklerinin Belirlenmesi
}

\author{
Yusuf DOĞAN* Muhammet Beșir CETIZ \\ Mardin Artuklu Üniversitesi Kızıltepe Meslek Yüksekokulu 47000, MARDİN \\ * e-posta: yusufdogan@artuklu.edu.tr ; Tel: 0 (482) 22510 56- 2037
}

Özet: Bu araştırma, Mardin-Kızıltepe ekolojik koşullarında bazı makarnalık buğday çeşitlerinin verim ve kalite özelliklerinin belirlenmesi amacıyla yürütülmüsstür. Çalışmada tescil edilmiş 15 adet makarnalık buğday çeşidi (Fırat-93, Şahinbey, Diyarbakır-81, Aydın-93, Zühre, Ceylan-95, Sarıçanak, Eyyubi, Artuklu, Güneyyıldızı, Altıntoprak, Selçuk-87, Harran, Fuatbey ve Amanos) kullanılmıştır. Deneme Mardin-Kızlltepe kuru şartlarda 2012-2013 ve 2013-2014 yetişme sezonunda tesadüf blokları deneme desenine göre 3 tekerrürlü olarak kurulmuştur. Araştırmada kullanılan çeşitlerde bitki boyu 88.2-112.9 $\mathrm{cm}$, başak uzunluğu 5.9-7.5 cm; başakta başakçık sayısı, 15.0-29.8 adet; başaktaki tane sayısı, 23.8-52.6 adet; tane verimi, 286.9-477.3 kg/da; bin tane ağırlığı, 37.3-47.1g; hektolitre ağırlığı, 77.1-82.6 kg; protein oranı, \% 10.4-15.7 ve zeleny sedimantasyon testi 13.3-27.6 ml arasında değişmiştir. Elde edilen sonuçlara göre Mardin-Kızıltepe bölgesi için tane verimi bakımından Şarıçanak çeşidi, protein oranı bakımından Zühre ve hem tane verimi hem de kalite bakımından Sarıçanak, Artuklu ve Zühre çeşitleri ön plana çıkmıştır.

Anahtar kelimeler: Makarnalık buğday, Adaptasyon, Verim, Kalite, Verim bileşenleri

\section{Determination of Yield And Quality Traits in Registered Durum Wheat (Triticum durum L.) Cultivars of Turkey in Mardin - Kızltepe Conditions}

\begin{abstract}
This research, was conducted to determine the yield and quality characteristics of some durum wheat cultivars in Mardin-Kiziltepe ecological conditions. In this study, 15 bread wheat cultivars ((Frrat93, Şahinbey, Diyarbakır-81, Aydın-93, Zühre, Ceylan-95, Sarıçanak, Eyyubi, Artuklu, Güneyyıldızı, Altıntoprak, Selçuk-87, Harran, Fuatbey and Amanos) were used. Dry conditions based on Randomized Complete Block Design with 3 replications was established Mardin-Kızıltepe trial in during the growing season 2012-2013 and 2013-2014. In the studied cultivars, plant height range from 88.2 to112.9 cm, spike length range from 5.9 to $7.5 \mathrm{~cm}$, spikelets per spike the range from 15.0 to 29.8 units, the spike in the number of grains range from 23.8 to 52.6 units per spike, grain yield range from 2869 to $4773 \mathrm{~kg} / \mathrm{ha}$, thousand grain weight range from 37.3 to 47.1 , range from 77.1 to $82.6 \mathrm{~kg}$ test weight, range from $\% 10.4$ to 15.7 protein, and zeleny sedimentation test ranged from 13.3 to $27.6 \mathrm{ml}$. Based on the results, cv. Sarıçanak was recommended for grain yield and cv. Zühre was protein while cultivars Sarıçanak, Artuklu and Zühre were recommended for both grain yield and quality for the Mardin-Kızlltepe region.
\end{abstract}

Key words: Durum wheat, Adaptation, Yield, Quality, Yield components

\section{Giriş}

Birçok ülkede Türkiye'de olduğu gibi temel gıda maddesi buğdaydır. Ekmek çeşitleri baş̧a olmak üzere makarna, bulgur, erişte, kuskus, bisküvi, kraker, gofret, kek, simit, poaça, kahvaltılık gevrekler, çerez gıdalar, nişasta, vital gluten ve nişasta bazlı şekerler gibi birçok gıdanın üretiminde kullanılmaktadır. Buğdayın öğütülmesi sonucunda elde edilen kepek ise, çoğunlukla yem sanayinde değerlendirilmektedir (Hoseney 1994; Elgün and Ertugay 1995; Bushuk 1998).

Serin iklim tahıllarının en önemlisi olan buğday dünya'da diğer ürünlere göre daha geniş bir alanda yetiştirilmekte olup, insan beslenmesinde en önemli kalori ve protein kaynağıdır. 2014 yılı verilerine 
göre, makarnalık buğday ekim alanı Türkiye de 1.282.464 hektar, üretim 3.3 milyon ton, ortalama verim yaklaşık $260 \mathrm{~kg} / \mathrm{da}$ civarındadır. Mardin de ise ekim alanı 101.006 hektar, üretim 395.172 ton, ortalama verim $391 \mathrm{~kg} / \mathrm{da}$ civarında olup, Türkiye ortalamasının oldukça üstündedir (TÜİK 2014). Türkiye iklim koşulları yönünden makarnalık buğday üretiminde birçok ülkeye oranla daha avantajlı bir konuma sahiptir. Özellikle makarnalık buğdayın gen merkezi olmasına rağmen, makarna sanayisinin hammadde ihtiyacı çoğunlukla ithalat yoluyla karşılanmaktadır. Bu durumun temel sebebi makarnalık buğdaya uygulanan tarımsal politikaların ve desteklerin yeterli olmayışıdır.

Makarnalık buğdayda en temel kalite kriteri olan protein oranı; miktarı ve kalitesi genotip ile birlikte çevre faktörlerinin etkisi altındadır. Bu etkide genotipin payı daha fazladır. Ayrıca yetişme süresince düşen yağışın miktarı ve dağılımı, sıcaklık, topraktan alınan su, organik maddeler ve azotlu gübre miktarı protein miktarını önemli ölçüde etki etmektedir. İyi bir makarnalık buğdayda protein oranının \% 13'den fazla olması gerekmektedir (Özkaya and Özkaya 1993). Makarnalık kalitesini belirlemede etkin rolü olan camsılık da çevre koşullarından büyük ölçüde etkilenmektedir. Camsılık ile irmik verimi arasında doğru orantı bulunmaktadır (Kün 1988, Atlı ve ark. 1993).

$\mathrm{Bu}$ araştırmada; makarnalık buğday üretiminde verimi kısıtlayan en önemli faktörler uygun çeşit ve sertifikalı tohumluk kullanılmamasıdır. Bu temel sorunların çözülmesi durumunda birim alandan daha fazla ürün alınarak, piyasaya daha fazla ürün arzı olacaktır. Bu amaçla yapılan araştırmada, farklı makarnalık buğday çeşitleri kullanılmak suretiyle bölgeye verim ve kalite bakımından en yüksek verime sahip çeşitlerin tespiti yapılmıştır.

\section{Materyal ve Metot}

Araştırmada tescil edilmiş 15 makarnalık buğday çeşidi (Fırat-93, Şahinbey, Diyarbakır-81, Aydın-93, Zühre, Ceylan-95, Sarıçanak, Eyyubi, Artuklu, Güneyyıldızı, Altıntoprak, Selçuklu-97, Harran, Fuatbey ve Amanos) kullanılmıştır. Bu araştırma, 2012-2013 ve 2013-2014 yetiştirme dönemlerinde iki yıl süreyle Mardin Artuklu Üniversitesi Kızıltepe Meslek Yüksekokulu deneme alanlarında yürütülmüştür. Tesadüf Blokları Deneme Desenine göre üç tekrarlamalı olarak yürütülen deneme, kuru tarım koşullarında kışlık olarak kurulmuştur. Denemede tüm çeşitler için $20 \mathrm{~cm}$ sira aralığı uygulanmış, metrekareye 500 tohum denk gelecek şekilde parsele atılacak tohumluk miktarları hesaplanarak ekim yapılmıştır. Her parsele eşit olarak dekara $16 \mathrm{~kg}$ gelecek şekilde DAP (Diamonyum fosfot, 18-46-0) gübresi ekimle birlikte, $6 \mathrm{~kg} / \mathrm{da}$ saf azot denk gelecek şekilde amonyum sülfat gübresi kardeşlenme döneminde toprağa verilmiştir. Sulama yapılmamış, her iki yılda da parseller otlandıkça yabancı ot mücadelesi elle yapılmıştır. Denemede parsel büyüklüğü $5 \mathrm{~m} \mathrm{x} 1 \mathrm{~m}=5 \mathrm{~m}^{2}$ olarak tutulmuştur. Denemede, parseller arasında $1 \mathrm{~m}$, bloklar arasında ise $2 \mathrm{~m}$ boşluk bırakılmıştır. Ekim işlemi ilk yıl 25.11.2012 tarihinde ikinci yıl ise 24.11.2013 tarihinde markörle açılan çizilere elle yapılmış, hasat çeşitlere göre değişmek üzere her iki yılda da Haziran ayının başlarında elle yapılmıştır. Hasatta, yanlardan birer sıra başlardan ise $0.5 \mathrm{~m}$ kenar tesiri olarak atıldıktan sonra bütün işlemler $4 \mathrm{~m}$ x $0.6=2.4 \mathrm{~m}^{2}$ 'lik alan üzerinde yapılmıştır. Hasat edilen bitkiler uygun bir yerde harman olgunluğuna gelinceye kadar kurutularak, daha sonra elle harmanlanmıştır. Denemenin yürütüldüğü dönemi kapsayan aylara ait iklim verileri ile uzun yıllar ortalaması Çizelge 1'de verilmiştir (Anonim 2014).

Çizelge 1. Deneme alanının iklim verileri (Anonim 2014 )

\begin{tabular}{|c|c|c|c|c|c|c|c|c|c|}
\hline \multirow{3}{*}{ Aylar } & \multicolumn{3}{|c|}{ Ortalama Sicaklık $\left({ }^{\circ} \mathrm{C}\right)$} & \multicolumn{2}{|c|}{ Yağıș (mm) } & \multicolumn{4}{|c|}{ Nispi Nem (\%) } \\
\hline & & & UYO & & & UYO & & & UYO \\
\hline & $2012-13$ & 2013-14 & LTA & 2012-13 & 2013-14 & LTA & $2012-13$ & 2013-14 & LTA \\
\hline Ekim & 19.0 & 19.1 & 18.3 & 65.4 & 0.4 & 36.2 & 44.6 & 22.6 & 46 \\
\hline Kasım & 13.0 & 13.7 & 10.7 & 93.1 & 3.8 & 69.7 & 52.1 & 52.5 & 57 \\
\hline Aralık & 5.2 & 4.5 & 5.3 & 192.5 & 3.4 & 106.9 & 66.4 & 52.3 & 67 \\
\hline Ocak & 4.9 & 6.1 & 3.0 & 152.7 & 85.5 & 112.3 & 68.0 & 59.5 & 70 \\
\hline Şubat & 6.6 & 7.5 & 4.0 & 105.4 & 42.0 & 108.2 & 71.0 & 43.1 & 66 \\
\hline Mart & 9.1 & 10.7 & 8.0 & 53.7 & 62.0 & 96.8 & 52.1 & 45.0 & 61 \\
\hline Nisan & 15.2 & 15.9 & 13.4 & 62.3 & 34.9 & 83.6 & 46.0 & 41.9 & 56 \\
\hline Mayıs & 19.5 & 21.2 & 19.6 & 154.4 & 14.7 & 40.4 & 43.0 & 32.5 & 45 \\
\hline Toplam & & & & 879.5 & 248.5 & 662.7 & & & \\
\hline Ortalama & 11.5 & 14.0 & 10.3 & & & & 55.6 & 41.1 & 58.5 \\
\hline
\end{tabular}

Mardin meteoroloji Bölge Müdürlüğü UYO: Uzun yıllar ortalamas1 
Çizelge 1. Deneme alanının iklim verileri Denemin yapıldığı 2012-2013 ve 2013-2014 vejetasyon dönemine ait aylık toplam yağış ve aylık ortalama sıcaklık değerleri Çizelge 1'de verilmiştir. Birinci yıl yıllık toplam yağış miktarı $879.5 \mathrm{~mm}$ iken ikinci yıl $248.5 \mathrm{~mm}$ olarak gerçekleşmiştir. Uzun yıllar ortalama değerleri incelendiğinde $(662.7 \mathrm{~mm})$ ilk yılda düşen toplam yağış miktarı uzun yıllar ortalamasın göre daha yüksek iken, ikinci yılda düşen toplam yăğıs miktarı uzun yıllar ortalamasından oldukça düşüktür. Uzun yıllar ortalama değerlerine göre sıcaklık $10.3{ }^{0} \mathrm{C}$ ve nispi nem \% 58.5 olarak gerçekleşmiştir. Denemenin kurulduğu topraklar; alüviyal ana materyalli, düz ve düze yakın derin topraklardır. Tipik kırmızı renkli, killi tekstürlüdür. Tuz içeriği \% 0.059, pH’sı 7.59, kireç oranı \% 29.6, organik madde içeriği \% 1.69, fosfor $(57.8 \mathrm{ppm})$ ve potasyum içeriği ise $(1.66 \mathrm{me} / 100 \mathrm{~g})$ olarak ölçülmüştür.

Çalışmada her parselden rastgele alınan 10 bitkideki ölçüm ve tartımlar (Genç ve ark. 1987)'ın uyguladıkları yöntemler esas alınarak incelenmiştir. Elde edilen iki yıllık sonuçlar, yıllar ayrı ayrı ve birleştirerek varyans analizine tabi tutulmuş, ortalamalar arasındaki farklar LSD $(\mathrm{p}<0.05)$ çoklu karşılaştırma yöntemine göre test edilmiştir.

\section{Bulgular ve Tartışma}

Makarnalık buğday çeşitlerinde verim ve kalite açısından bazı tarımsal özellikler üzerine etkisine ait varyans analiz sonuçları Çizelge 2'de, araştırmada incelenen özelliklere ilişkin ortalamalar ve Duncan'a göre farklılık gruplandırmaları Çizelge 3, 4 ve 5'da verilmiştir.

Çizelge 2'de verilen varyans analiz sonuçlarına göre çeşitler açısından incelediğimizde birinci yıl, ikinci yıl ve iki yıl birleştirilmiş ortalamalar incelenen bütün özellikler istatistiksel olarak \%1 düzeyinde önemli bulunmuştur. Y1l x çeşit interaksiyonu incelendiğinde ise incelenen bütün özellikler önemsiz çıkmıştır.

Çizelge 2. Buğday çeşitlerinin bazı özellikler üzerine ait varyans analiz sonuçları

\begin{tabular}{llcll}
\hline İncelenen özellikler & \multicolumn{2}{c}{ Çeşit } & \multicolumn{2}{l}{ Yillar } \\
& $2012-13$ & $2013-14$ & (Birleştirilmiş) & \\
\hline Bitki boyu & $176.7^{* *}$ & $209.7^{* *}$ & $378.3^{* *}$ & 8,02 öd \\
Başak boyu & $0.8^{*}$ & $0.97^{* *}$ & $1.80^{* *}$ & 0,02 öd \\
Başakta tane sayısı & $169.7^{* *}$ & $175.4^{* *}$ & $344.1^{* *}$ & 1,03 öd \\
Başakta başakçık sayısı & $30.6^{* *}$ & $35.3^{* *}$ & $65.6^{* *}$ & 0,26 öd \\
Bin tane ağırlığ1 & $27.5^{* *}$ & $27.7^{* *}$ & $55.04^{* *}$ & 0,13 öd \\
Tane verimi & $8344^{* *}$ & $8454^{* *}$ & $16761^{* *}$ & 37,8 öd \\
Hektolitre & $7.9^{* *}$ & $7.65^{* *}$ & $15.4^{* *}$ & 0,09 öd \\
\hline Protein oranı & $4,9^{* *}$ & $4.99^{* *}$ & $9.75^{* *}$ & 0,14 öd \\
\hline Sedimantasyon & $39,4^{* *}$ & $46.3^{* *}$ & $84.5^{* *}$ & 1,20 öd \\
\hline$* * \mathrm{P}<0.01$ düzeyinde önemli, $* \mathrm{P}<0.05$ düzeyinde önemli, öd: önemli değil &
\end{tabular}

Çizelge 3'te de görüldüğü üzere çeşitler bitki boyu açısından değerlendirildiğinde 2012-13, 2013-14 yıllarında ve iki yıl birleştirilmiş ortalamalarda en yüksek değerler sırasıyla 117.7, 108.2 ve $112.9 \mathrm{~cm}$ olarak Eyyubi çeşidinden elde edilmiştir. En düşük değerler ise sırasıyla Fırat-93, Fuatbey, Aydın-93, Harran ve Amanos çeşitlerinden elde edilirken, arasındaki fark istatistiksel olarak önemsiz bulunmuştur. Buğdayda bitki boyu; çeşidin genetik yapısı, ekim sıklı̆̆ı, ekim zamanı, gübreleme, yağış durumu ve toprak özelliklerine bağlı olarak değişmektedir (Kün 1988). Ayrıca yapılan araştırmalarda bitki boyunun genotiplere ve çevre şartlarına bağlı olarak değiştiği bildirilmektedir (Whitman ve ark. 1985). Konu ile ilgili yapılan benzer çalışmalarda bitki boyu uzunluğunun, Kara ve ark. (2008) 91.5-118.7 cm, Kaya ve ark. (2009) 75.5-84.4 cm, Kendal ve ark. (2011), 95-135 cm arasında değiştiğini bildirmişlerdir. Söz konusu araştırıcıların sonuçları ile çalışmamızın sonuçları örtüşmektedir. Yıllara bağlı olarak bitki boyu bakımından çeşitler arasındaki farklılıklar oluşmuştur. İkinci yıl bitki boyundaki azalma vejetatif gelişme döneminde düşen yağışın az olmasıyla açıklanabilir. Nitekim bitki boyu hem genotip hem de yetiştirme koşullarına bağlı olarak değişmektedir (Genç ve ark. 1992). 
Çizelge 3. Makarnalık buğday çeşitlerinde bitki boyu, başak boyu ve başakta başakçık sayısı ilişkin oluşan gruplar ve ortalamalar*.

\begin{tabular}{|c|c|c|c|c|c|c|c|c|c|}
\hline \multirow[t]{2}{*}{ Çeşitler } & \multicolumn{3}{|c|}{ Bitki boyu } & \multicolumn{3}{|c|}{ Başak uzunluğu } & \multicolumn{3}{|c|}{ Başakta başakçık sayısı } \\
\hline & 1.y1l & 2.y1l & Ortalama & 1.y1l & 2.y1l & Ortalama & 1.y1l & 2.y1l & Ortalama \\
\hline Firat-93 & $94.1 \mathrm{ef}$ & $82.4 \mathrm{f}$ & $88.2 \mathrm{e}$ & $6.0 \mathrm{~d}$ & $5.7 \mathrm{~d}$ & $5.9 \mathrm{e}$ & $15.7 \mathrm{~d}$ & $14.3 \mathrm{~d}$ & $15.0 \mathrm{e}$ \\
\hline Şahinbey & $100.6 \mathrm{cf}$ & $87.1 \mathrm{df}$ & $93.8 \mathrm{de}$ & $6.2 \mathrm{bd}$ & $6.1 \mathrm{bd}$ & $6.2 \mathrm{ce}$ & $19.8 \mathrm{~cd}$ & $18.5 \mathrm{~cd}$ & $19.2 \mathrm{~cd}$ \\
\hline Diyarbakır-81 & $106.1 \mathrm{bc}$ & $90.5 \mathrm{cf}$ & $98.3 \mathrm{~cd}$ & $7.8 \mathrm{a}$ & $7.3 \mathrm{a}$ & $7.4 \mathrm{a}$ & $19.4 \mathrm{~cd}$ & $19.1 \mathrm{c}$ & $19.2 \mathrm{~cd}$ \\
\hline Aydin-93 & $93.2 \mathrm{f}$ & $83.2 \mathrm{f}$ & $88.2 \mathrm{e}$ & $6.1 \mathrm{~cd}$ & $5.9 \mathrm{~cd}$ & $6.0 \mathrm{e}$ & $20.9 \mathrm{c}$ & $19.8 \mathrm{c}$ & $20.4 \mathrm{~cd}$ \\
\hline Zühre & 110.6 ac & $97.3 \mathrm{ad}$ & $103.5 \mathrm{bc}$ & $7.0 \mathrm{ad}$ & $6.8 \mathrm{ad}$ & $6.9 \mathrm{ac}$ & $25.5 \mathrm{~b}$ & $24.6 \mathrm{~b}$ & $25.0 \mathrm{~b}$ \\
\hline Ceylan-95 & $102.4 \mathrm{dt}$ & $93.7 \mathrm{bf}$ & $98.1 \mathrm{~cd}$ & $6.7 \mathrm{ad}$ & $6.9 \mathrm{ac}$ & $6.8 \mathrm{ad}$ & $19.8 \mathrm{~cd}$ & $18.9 \mathrm{c}$ & $19.4 \mathrm{~cd}$ \\
\hline Sarıçanak & $106.6 \mathrm{bc}$ & $92.8 \mathrm{cf}$ & $99.7 \mathrm{~cd}$ & $7.1 \mathrm{ac}$ & $6.8 \mathrm{ad}$ & $6.9 \mathrm{ab}$ & $21.4 \mathrm{bc}$ & $20.8 \mathrm{bc}$ & $21.1 \mathrm{c}$ \\
\hline Eyyubi & $117.7 \mathrm{a}$ & $108.2 \mathrm{a}$ & $112.9 \mathrm{a}$ & $6.9 \mathrm{ad}$ & $6.8 \mathrm{ad}$ & $6.8 \mathrm{ad}$ & $20.5 \mathrm{c}$ & $19.3 \mathrm{c}$ & $19.9 \mathrm{~cd}$ \\
\hline Artuklu & $113.7 \mathrm{at}$ & $105.5 \mathrm{ab}$ & $109.6 \mathrm{ab}$ & $7.6 \mathrm{a}$ & $7.5 \mathrm{a}$ & $7.5 \mathrm{a}$ & $20.5 \mathrm{c}$ & $19.5 \mathrm{c}$ & $20.0 \mathrm{~cd}$ \\
\hline Güneyyıldızı & $107.4 \mathrm{ac}$ & $99.7 \mathrm{ac}$ & $103.6 \mathrm{bc}$ & $7.2 \mathrm{ab}$ & $7.1 \mathrm{ab}$ & $7.2 \mathrm{ab}$ & $22.2 \mathrm{bc}$ & $20.4 \mathrm{bc}$ & $21.3 \mathrm{c}$ \\
\hline Altıntoprak & $103.8 \mathrm{ce}$ & $93.4 \mathrm{bf}$ & $98.6 \mathrm{~cd}$ & $7.3 \mathrm{a}$ & $7.1 \mathrm{ab}$ & $7.2 \mathrm{a}$ & $20.1 \mathrm{c}$ & $19.2 \mathrm{c}$ & $19.6 \mathrm{~cd}$ \\
\hline Selçuklu-97 & $104.6 \mathrm{bc}$ & 95.6 be & $100.1 \mathrm{~cd}$ & $6.2 \mathrm{bd}$ & $6.0 \mathrm{bd}$ & $6.1 \mathrm{ce}$ & $18.6 \mathrm{~cd}$ & $17.4 \mathrm{~cd}$ & $18.0 \mathrm{~d}$ \\
\hline Harran & $95.5 \mathrm{df}$ & $83.5 \mathrm{ef}$ & $89.5 \mathrm{e}$ & $6.2 \mathrm{bd}$ & $6.9 \mathrm{~cd}$ & $6.1 \mathrm{de}$ & $19.5 \mathrm{~cd}$ & $18.3 \mathrm{~cd}$ & $18.9 \mathrm{~cd}$ \\
\hline Fuatbey & $93.2 \mathrm{f}$ & $82.8 \mathrm{f}$ & $88.0 \mathrm{e}$ & $6.5 \mathrm{ad}$ & $6.4 \mathrm{ad}$ & 6.5 be & $29.9 \mathrm{a}$ & $29.7 \mathrm{a}$ & $29.8 \mathrm{a}$ \\
\hline Amanos & $95.4 \mathrm{df}$ & $83.3 \mathrm{f}$ & $89.4 \mathrm{e}$ & $7.3 \mathrm{a}$ & $7.0 \mathrm{ac}$ & $7.2 \mathrm{ab}$ & $21.3 \mathrm{bc}$ & $20.8 \mathrm{bc}$ & $21.1 \mathrm{c}$ \\
\hline Ortalama & $103 \mathrm{~A}$ & $92 \mathrm{~B}$ & 97.5 & $6.8 \mathrm{~A}$ & $6.6 \mathrm{~A}$ & 6.7 & $21 \mathrm{~A}$ & $20 \mathrm{~A}$ & 20.5 \\
\hline $\mathrm{CK}(\%)$ & 6.1 & 7.9 & 6.9 & 9.2 & 10.3 & 9.7 & 12 & 12.7 & 12.4 \\
\hline Lsd (çeşit) & $10.4 * *$ & $2.2 * * \quad 7.8$ & & $1.05^{*}$ & $1.14^{*}$ & $0.76 * *$ & $4.24 * *$ & $4.30 * *$ & $2.95 * *$ \\
\hline Lsd (y1l) & $4.7^{* *}$ & & & $0.42 \mathrm{~ns}$ & & & $2.33 \mathrm{~ns}$ & & \\
\hline
\end{tabular}

*Aynı harfle gösterilen ortalamalar arasındaki farklılıklar önemsizdir. ${ }^{* *} \mathrm{P}<0.01$ düzeyinde önemli.

* $\mathrm{P}<0.05$ düzeyinde önemli.

Başak uzunluğu yönünden çeşitler incelendiğinde en uzun başak boyları her iki yetiştirme sezonunda ve birleştirilmiş ortalamalarda Altıntoprak çeşidinden elde edilirken, Diyarbakır-81 ve Artuklu çeşitleri ile arasındaki fark önemsiz çıkmıştır. En kısa başak uzunluğu ise Fırat-93 çeşidinde elde edilmekle beraber Aydın-93 çeşidi ile arasındaki fark istatistiksel açıdan önemsiz bulunmuştur. Sakin ve ark. (2004), başak uzunluğunun 5.5-7.2 cm arasında değiştiğini, Akıncı ve Yıldırım (2009), başak uzunluğunun 5.27-7.38 $\mathrm{cm}$ arasında değiştiğini bildirmişlerdir. Başak uzunluğu bakımından çeşitlerler arasında görülen varyasyonun en önemli nedeni, denemede kullanılan materyallerin genetik yapısının farklı olmasıdır (Akman ve ark. 1999). Başak uzunluğu fazla olan Artuklu çeşidi tane verimi de yüksek bulunmuştur (Çizelge 4.14). Çeşitler arasında başak uzunluğu bakımından görülen farklılıklar çeşit özelliklerinin farklı olmasından kaynaklanmaktadır (Genç ve ark. 1992).

Başakta başakçık sayısı yönünden çeşitler incelendiğinde en fazla başakçık sayısı her iki yetiştirme sezonunda ve birleştirilmiş ortalamalarda Fuatbey çeşidinden elde edilirken, en düşük sayı ise Frrat-93 çeşidinde elde edilmiştir. Aksoy (2012), Çukurova koşullarında makarnalık buğday çeşitlerinde yapmış olduğu çalışmada başakta başakçık sayısının 18.0-25.9 adat arasında değiştiği bildirmiştir. Akıncı ve Yıldırım (2009), Diyarbakır ekolojik koşullarında yapmış oldukları çalışmada makarnalık buğday çeşitlerinde başakta başakçık sayısının 16.4-21.8 adet arasında değiştiği bildirmişlerdir. Denemede çeşitlerin başakta başakçık sayısına dair elde edilen veriler, araştırmacıların verileriyle paralellik göstermektedir.

Başakta tane sayısı yönünden çeşitler incelendiğinde başakta en fazla tane sayısı her iki yetiştirme sezonunda ve birleştirilmiş ortalamalarda Sarıçanak çeşidinden elde edilirken, en düşük sayı ise Fırat-93 çeşidinde elde edilmiştir.

Ayçiçek ve Yıldırım (2006), 29.5-45.2 adet, Akıncı ve Yıldırım (2009), başakta tane sayısının 30.2-51.7 adet, Aksoy (2012), başakta dane sayısı 39.5-64.8 dane arasında değiştiğini bildirmişlerdir. Bu çalışmada elde edilen bulgular araştırmacıların bulguları ile uyumlu bulunmuştur. Başakta dane sayısının artmasıyla birlikte buğdayda verimde artmaktadır. Tane verimindeki artışların bin tane ağırlıklarından çok başaktaki dane sayısının artmasından kaynaklandığını bildirmektedir. (Ayoub ve ark., 1994), Başaktaki tane sayısının tane verimine etkisinin, tanelerinin dolgun olması halinde mümkün olabileceğini bildirmişlerdir. 
Çeşitler bin tane ağırlığı yönünden ele alındığında, en yüksek değerler Firat-93 çeşidinden elde edilirken, en düşük değerler Diyarbakır-81 çeşidi ile beraber Fuatbey çeşidinde elde edilmiş ve arasındaki fark istatistiksel yönden önemsiz bulunmuştur. Konu ile ilgili yapılan benzer çalışmalarda buğdayda bin tane ağırlığının genotiplere ve çevre şartlarına göre önemli varyasyonlar gösterdiği belirtilmektedir (Akman ve ark. 1999). Makarnalık buğday üzerinde ülkemizin farklı bölgelerinde yapılan çalışmalarda alınan sonuçlarda Kendal ve ark. (2011), bin tane ağırlığını 30.0-42.8 g, Akgün ve ark. (2011), 38.21-40.94 g, Kılıç ve ark. (2007), 30.3-38.3 g arasında bulmuş olup araştırmamızdan elde edilen değerlerle uyum içerisinde olduğu görülmektedir. $\mathrm{Bu}$ da bin tane ağırlığının çevreden daha çok genetik yapıdan etkilendiğini göstermektedir (Blue ve ark. 1990).

Çizelge 4.4. Makarnalık buğday çeşitlerinde başakta tane sayısı, bin tane ağırlı̆̆ı ve tane verimine ilişkin oluşan gruplar ve ortalamalar.*

\begin{tabular}{|c|c|c|c|c|c|c|c|c|c|}
\hline \multirow[t]{2}{*}{ Çeşitler } & \multicolumn{3}{|c|}{ Başakta tane sayısı } & \multicolumn{3}{|c|}{ Bin tane ağırlı̆̆1 } & \multicolumn{2}{|c|}{ Tane verimi } & \multirow[b]{2}{*}{ Ortalama } \\
\hline & 1.y1l & 2.y1l & Ortalama & 1.y1l & yil & alama & 1.y1l & 2.y1l & \\
\hline Firat-93 & $24.8 \mathrm{~d}^{*}$ & $22.8 \mathrm{e}$ & $23.8 \mathrm{~h}$ & $47.6 \mathrm{a}$ & $46.5 \mathrm{a}$ & $47.1 \mathrm{a}$ & 392.1 be & 361.3 be & $376.7 \mathrm{cf}$ \\
\hline Şahinbey & $32.1 \mathrm{~cd}$ & $30.6 \mathrm{ce}$ & $31.3 \mathrm{fh}$ & $45.6 \mathrm{ab}$ & $45.0 \mathrm{ab}$ & $45.3 \mathrm{ac}$ & $364.0 \mathrm{ce}$ & 329.9 ce & $346.9 \mathrm{dh}$ \\
\hline Diyarbakır-81 & $33.8 \mathrm{~cd}$ & $32.3 \mathrm{ce}$ & $33.1 \mathrm{eg}$ & $37.8 \mathrm{f}$ & $36.9 \mathrm{f}$ & $37.3 \mathrm{f}$ & $306.4 \mathrm{e}$ & $267.4 \mathrm{e}$ & $286.9 \mathrm{~h}$ \\
\hline Aydın-93 & $43.9 \mathrm{ac}$ & $42.2 \mathrm{ac}$ & $43.1 \mathrm{bc}$ & $40.3 \mathrm{cf}$ & $39.5 \mathrm{cf}$ & 39.9 ef & $328.1 \mathrm{de}$ & $287.7 \mathrm{de}$ & $307.9 \mathrm{gh}$ \\
\hline Zühre & $36.6 \mathrm{bd}$ & $35.1 \mathrm{bc}$ & $35.8 \mathrm{cf}$ & $39.4 \mathrm{df}$ & $38.9 \mathrm{df}$ & 39.1 ef & $427.6 \mathrm{ac}$ & $392.8 \mathrm{ac}$ & $410.2 \mathrm{bd}$ \\
\hline Ceylan-95 & $34.2 \mathrm{~cd}$ & $32.4 \mathrm{ce}$ & $33.3 \mathrm{eg}$ & $43.4 \mathrm{bf}$ & $42.7 \mathrm{ad}$ & $43.1 \mathrm{~cd}$ & $333.2 \mathrm{de}$ & $291.5 \mathrm{de}$ & $312.4 \mathrm{fh}$ \\
\hline Sarıçanak & $53.1 \mathrm{a}$ & $52.0 \mathrm{a}$ & $52.6 \mathrm{a}$ & 42.0 be & 41.4 be & $41.7 \mathrm{de}$ & $496.8 \mathrm{a}$ & $457.8 \mathrm{a}$ & $477.3 \mathrm{a}$ \\
\hline Eyyubi & $47.5 \mathrm{ab}$ & $45.9 \mathrm{ab}$ & $46.7 \mathrm{ab}$ & $45.6 \mathrm{ab}$ & $44.8 \mathrm{ab}$ & $45.2 \mathrm{ac}$ & 374.9 ce & 327.1 ce & $350.9 \mathrm{dh}$ \\
\hline Artuklu & $42.9 \mathrm{ac}$ & $40.8 \mathrm{ac}$ & $41.8 \mathrm{bd}$ & $43.9 \mathrm{ad}$ & $43.5 \mathrm{ac}$ & $43.7 \mathrm{bd}$ & $473.5 \mathrm{ab}$ & $434.5 \mathrm{ab}$ & $453.9 \mathrm{ab}$ \\
\hline Güneyyıldızı & $43.6 \mathrm{ac}$ & $42.4 \mathrm{ac}$ & $43.0 \mathrm{bc}$ & $46.4 \mathrm{a}$ & $46.5 \mathrm{a}$ & $46.5 \mathrm{ab}$ & $406.1 \mathrm{ad}$ & $374.4 \mathrm{ad}$ & 390.2 be \\
\hline Altıntoprak & $40.2 \mathrm{bc}$ & $40.9 \mathrm{ac}$ & 40.5 be & 42.2 be & 41.3 be & $41.8 \mathrm{de}$ & $436.9 \mathrm{ac}$ & $394.6 \mathrm{ac}$ & $415.7 \mathrm{ac}$ \\
\hline Selçuklu-97 & $33.1 \mathrm{~cd}$ & 33.4 ce & $33.3 \mathrm{eg}$ & $41.7 \mathrm{bf}$ & 41.4 be & $41.6 \mathrm{de}$ & 391.2 be & 355.5 be & $373.3 \mathrm{cf}$ \\
\hline Harran & $27.8 \mathrm{~d}$ & $26.5 \mathrm{de}$ & $27.2 \mathrm{gh}$ & $44.8 \mathrm{ac}$ & $43.6 \mathrm{ac}$ & $44.2 \mathrm{ad}$ & $409.8 \mathrm{ad}$ & $375.5 \mathrm{ad}$ & 392.6 be \\
\hline Fuatbey & $35.6 \mathrm{~cd}$ & 34.3 be & $34.9 \mathrm{cg}$ & 38.6 ef & 37.9 ef & $38.2 \mathrm{f}$ & $371.4 \mathrm{ce}$ & 342.3 be & $356.8 \mathrm{cg}$ \\
\hline Amanos & $35.5 \mathrm{~cd}$ & 32.9 ce & $34.2 \mathrm{dg}$ & $39.8 \mathrm{cf}$ & $39.4 \mathrm{cf}$ & $39.6 \mathrm{ef}$ & 357.9 ce & 324.5 ce & $341.2 \mathrm{eh}$ \\
\hline Ortalama & $37.6 \mathrm{~A}$ & $36.3 \mathrm{~A}$ & 36.9 & $42.6 \mathrm{~A}$ & $42 \mathrm{~A}$ & 42.3 & $391 \mathrm{~A}$ & $355 \mathrm{~B}$ & 372.8 \\
\hline $\mathrm{CK}(\%)$ & 18.80 & 19.40 & 19.00 & 5.90 & 6.00 & 5.98 & 14.10 & 15.90 & 14.90 \\
\hline Lsd (çesit) & $10.4 * *$ & $12.2 * *$ & $7.8 * *$ & $4.20 * *$ & $4.24 * *$ & $2.92 * *$ & $92.2 * *$ & $94.4 * *$ & $64.5^{* *}$ \\
\hline Lsd (yıl) & & $3.87 \mathrm{~ns}$ & & $1.03 \mathrm{~ns}$ & & & & $14.96 * *$ & \\
\hline
\end{tabular}

*Aynı harfle gösterilen ortalamalar arasındaki farklılıklar önemsizdir. ** $\mathrm{P}<0.01$ düzeyinde önemli. * $\mathrm{P}<0.05$ düzeyinde önemli.

Tane verimi özelliği açısından çeşitler incelendiğinde birinci yıl 306.4-496.8 kg/da, ikinci y1l 267.4-457.8 $\mathrm{kg} / \mathrm{da}$ ve iki yıl birleştirilmiş ortalamalarda 286.9 - $477.3 \mathrm{~kg} / \mathrm{da}$ arasında değişmiş olup en yüksek değerler Sarıçanak çeşidinden elde edilirken, Diyarbakır-81 çeşidi en düşük değerleri vermiştir. İkinci yılda tüm çeşitlerin tane verimi önemli ölçüde azalmıştır. Bu durum ikinci yılda vejetasyon döneminde düşen yağış miktarının az olmasıyla açıklanabilir (Çizelge 1). Genotiplerin verim özelliklerinde meydana gelen azalmalara bağlı olarak tane verimi de azalmıştır. Tulukcu ve Sade (2002), Konya da yaptıkları çalışmada dane verimi ortalamalarının 103.4-353.6 kg/da arasında değiştiğini, Sakin ve ark. (2004), dane veriminin 336.1-477.2 kg/da arasında değiştiğini, Ayçiçek ve Yıldırım (2006), tane veriminin 206-308 kg/da arasında değiştiğini, Akıncı ve Yıldırım (2009), Diyarbakır da yapmış oldukları çalışmada dane tane veriminin 227.1- $406.9 \mathrm{~kg} / \mathrm{da}$ arasında değişim gösterdiğini bildirmişlerdir. Araştırmacıların bulguları ile çalışmamızın bulguları uyum göstermektedir. Çeşitler arasında tane verimi bakımından oluşan farklılıkların çeşit özelliklerine ve çevre faktörlerine ( Genç ve ark. 1993; Aydın ve ark. 1999; Özberk ve Özberk 1993) bağlı olarak değiştiği bildirilmektedir.

Çeşitler hektolitre ağırlığı yönünden ele alındığında, en yüksek değerler Sarıçanak çeşidinden elde edilmekle beraber Eyyubi çeşidi ile arasındaki fark istatistiksel yönden önemsiz bulunurken, en düşük değerler Fırat-93 çeşidinden elde edilmiştir. Makarnalık buğday üzerinde ülkemizin farklı bölgelerinde yapılan çalışmalarda alınan sonuçlarda, hektolitre ağırlığının $73.8 \mathrm{~kg}$ (Akgün ve ark., 2011), $82.0 \mathrm{~kg}$ (Sakin ve ark., 2004), Kendal ve ark. (2011) 77.3-81.7 kg, Akgün ve ark.(2011), 73.41-79.04 kg, Kıllı̧ ve ark. (2007), 75.0-78.4 kg arasında bulmuş olup araştırmamızdan elde edilen değerlerle uyum içerisinde olduğu görülmektedir. Hektolitre ağırlığı yüksek Sarıçanak ve Eyyubi çeşitlerinin tane verimlerinin de yüksek olduğu görülmektedir (Çizelge 4.14). Hektolitre ağırlığının çeşit özelliğine, çevre faktörlerine, 
tane özelliklerine (tanede tekdüzelik, karın boşluğu, endosperm yapısı) bağlı olarak değiştiği bazı araştırıcılar tarafından bildirilmektedir.

Çizelge 4.5.Makarnalık buğday çeşitlerinde hektolitre ağırlığı, protein oranı ve sedimantasyona ilişkin oluşan gruplar ve ortalamalar*.

\begin{tabular}{|c|c|c|c|c|c|c|c|c|c|}
\hline \multirow[t]{2}{*}{$\overline{\text { Çeşitler }}$} & \multicolumn{3}{|c|}{ Hektolitre ağırlığ1 } & \multicolumn{3}{|c|}{ Protein oranı } & \multicolumn{3}{|c|}{ Sedimantasyon } \\
\hline & 1.y1l & 2.y1l & talama & 1.y1l & 2.y1l Orta & $\mathrm{ama}$ & 1.y1l & 2.y1l Ortal & ma \\
\hline Firat-93 & $76.4 \mathrm{e}^{*}$ & $77.8 \mathrm{~d}$ & $77.1 \mathrm{f}$ & $11.9 \mathrm{ef}$ & $13.6 \mathrm{~cd}$ & $12.7 \mathrm{~g}$ & $21.3 \mathrm{~b}$ & $22.9 \mathrm{~b}$ & $22.1 \mathrm{~b}$ \\
\hline Şahinbey & $79.7 \mathrm{ad}$ & $81.0 \mathrm{ac}$ & $80.3 \mathrm{bc}$ & $10.6 \mathrm{gh}$ & $11.5 \mathrm{f}$ & 11.11 & $14.5 \mathrm{df}$ & $15.5 \mathrm{fg}$ & $14.9 \mathrm{fh}$ \\
\hline Diyarbakır-81 & 77.9 be & $78.9 \mathrm{bd}$ & $78.4 \mathrm{df}$ & $12.4 \mathrm{ce}$ & $14.2 \mathrm{bd}$ & $13.3 \mathrm{dg}$ & $16.8 \mathrm{cf}$ & $17.7 \mathrm{dg}$ & $17.3 \mathrm{cg}$ \\
\hline Aydın-93 & $80.2 \mathrm{ac}$ & $81.3 \mathrm{ab}$ & $80.7 \mathrm{ab}$ & $13.2 \mathrm{bd}$ & $14.5 \mathrm{bc}$ & $13.8 \mathrm{bd}$ & $15.0 \mathrm{df}$ & $15.7 \mathrm{eg}$ & $15.3 \mathrm{eh}$ \\
\hline Zühre & 77.9 be & $79.2 \mathrm{bd}$ & $78.6 \mathrm{cf}$ & $15.1 \mathrm{a}$ & $16.2 \mathrm{a}$ & $15.7 \mathrm{a}$ & 17.3 be & $18.2 \mathrm{cg}$ & $17.7 \mathrm{cf}$ \\
\hline Ceylan-95 & $80.4 \mathrm{ab}$ & $81.1 \mathrm{ac}$ & $80.7 \mathrm{ab}$ & $12.3 \mathrm{de}$ & $13.9 \mathrm{bd}$ & $13.1 \mathrm{eg}$ & $14.1 \mathrm{ef}$ & $14.8 \mathrm{fg}$ & $14.4 \mathrm{gh}$ \\
\hline Sarıçanak & $82.1 \mathrm{a}$ & $83.1 \mathrm{a}$ & $82.6 \mathrm{a}$ & $13.4 \mathrm{bc}$ & $14.1 \mathrm{bd}$ & $13.7 \mathrm{be}$ & $13.0 \mathrm{f}$ & $13.7 \mathrm{~g}$ & $13.3 \mathrm{~h}$ \\
\hline Eyyubi & $81.8 \mathrm{a}$ & $83.4 \mathrm{a}$ & $82.6 \mathrm{a}$ & $12.7 \mathrm{be}$ & $14.1 \mathrm{bd}$ & $13.4 \mathrm{cg}$ & $15.9 \mathrm{cf}$ & $16.5 \mathrm{dg}$ & $16.2 \mathrm{dh}$ \\
\hline Artuklu & $79.9 \mathrm{ad}$ & $80.9 \mathrm{ac}$ & $80.4 \mathrm{bc}$ & $13.5 \mathrm{~b}$ & $14.8 \mathrm{~b}$ & $14.2 \mathrm{~b}$ & $16.1 \mathrm{cf}$ & 20.3 be & $18.2 \mathrm{ce}$ \\
\hline Güneyyıldızı & $77.4 \mathrm{de}$ & $78.4 \mathrm{~cd}$ & $77.9 \mathrm{ef}$ & $13.4 \mathrm{~b}$ & $14.5 \mathrm{bc}$ & $13.9 \mathrm{bc}$ & $19.6 \mathrm{bc}$ & $20.5 \mathrm{bd}$ & $20.1 \mathrm{bc}$ \\
\hline Altıntoprak & $79.6 \mathrm{ad}$ & $81.1 \mathrm{ac}$ & $80.3 \mathrm{bc}$ & 12.6 be & $14.1 \mathrm{bd}$ & $13.3 \mathrm{cg}$ & $14.6 \mathrm{df}$ & $15.2 \mathrm{fg}$ & $14.9 \mathrm{fh}$ \\
\hline Selçuklu-97 & 77.6 ce & $79.1 \mathrm{bd}$ & $78.3 \mathrm{df}$ & 12.9 be & $14.2 \mathrm{bd}$ & $13.5 \mathrm{bf}$ & $18.2 \mathrm{bd}$ & $19.2 \mathrm{bf}$ & $18.7 \mathrm{~cd}$ \\
\hline Harran & 78.2 be & $79.5 \mathrm{bd}$ & $78.8 \mathrm{cf}$ & $12.3 \mathrm{de}$ & $13.8 \mathrm{~cd}$ & $13.1 \mathrm{fg}$ & $15.6 \mathrm{cf}$ & $16.2 \mathrm{dg}$ & $15.9 \mathrm{dh}$ \\
\hline Fuatbey & $79.4 \mathrm{ad}$ & $80.7 \mathrm{ac}$ & $80.1 \mathrm{bd}$ & $9.9 \mathrm{~h}$ & $10.8 \mathrm{f}$ & $10.4 \mathrm{j}$ & $26.9 \mathrm{a}$ & $28.3 \mathrm{a}$ & $27.6 \mathrm{a}$ \\
\hline Amanos & $78.4 \mathrm{ad}$ & $79.7 \mathrm{bd}$ & 79.0 be & $11.2 \mathrm{fg}$ & $12.8 \mathrm{de}$ & $12.0 \mathrm{~h}$ & $20.9 \mathrm{~b}$ & $22.7 \mathrm{bc}$ & $21.8 \mathrm{~b}$ \\
\hline Ortalama & $79.1 \mathrm{~B}$ & $80.3 \mathrm{~A}$ & 79.7 & $12.5 \mathrm{~B}$ & $13.8 \mathrm{~A}$ & 13.2 & 17.3 B & $18.5 \mathrm{~A}$ & 17.9 \\
\hline $\mathrm{CK}(\%)$ & 1.9 & 2.0 & 2.0 & 4.9 & 3.6 & 4.2 & 14.2 & 15.30 & 14.8 \\
\hline Lsd (çeşit) & $2.64 * *$ & $2.71 * *$ & & $1.03 * *$ & $0.83 * *$ & $0.64 * *$ & $4.1 * *$ & $4.73 * *$ & $3.06^{* *}$ \\
\hline Lsd (yıl) & & $0.69 * *$ & & & $0.33 * *$ & & & $0.48 * *$ & \\
\hline
\end{tabular}

*Aynı harfle gösterilen ortalamalar arasındaki farklılıklar önemsizdir. ${ }^{* *} \mathrm{P}<0.01$ düzeyinde önemli.

$* \mathrm{P}<0.05$ düzeyinde önemli.

Çeşitlerin protein oranı üzerine etkisi incelendiğinde hem denemenin birinci ve ikinci yılında hem de iki yıllık birleştirilmiş ortalamalarda en yüksek değerler Zühre çeşidinden elde edilirken, en düşük değerler Fuatbey çeşidinde elde edilmiştir. Ünal (2003), buğdayda protein miktarının tür, çeşit, çevre koşulları ve üretim tekniğine bağlı olarak \% 6-22 arasında değiştiğini ve yurdumuzda protein miktarının topbaşlarda \% 9-13, ekmeklik buğdaylarda \% 10-15, makarnalık buğdaylarda \%11-17 arasında değiştiğini bildirmektedir. Protein oranı bakımından genotipler arasında önemli farkların olduğu birçok araştırıcı tarafından da bildirilmiştir (Gökmen ve Sencar, 1989; Budak ve ark., 1997). Kılıç (2003) danede protein oranına yıllık yağış miktarı yanında, dane doldurma dönemindeki yüksek sıcaklıklar ve topraktaki azot miktarının da etkisi olduğunu ve değerlendirmede bunlarında göz önüne alınması gerektiğini belirtmiştir. Araştırmada kullanılan makarnalık buğday çeşitlerinin protein oranı bakımından varyasyona sahip olduğu belirlenmiştir.

2012-13, 2013-14 yıllarında ve iki yıl birleștirilmiş ortalamalarda en yüksek sedimantasyon değerleri sırasıyla 26.9, 28.3 ve $27.6 \mathrm{ml}$ olarak Fuatbey çeşidinden elde edilirken, en düşük değerler Sarıçanak çeşidinden elde edilmiştir. Aksoy (2012), Adana yaptığı makarnalık buğday çeşitleri çalışmasında sedimantasyon ortalama değerlerinin 16.7-42.2 ml arasında değiştiğini, Aydoğan ve ark., (2012), Konya lokasyonunda yaptıkları araştırma ise sedimantasyon ortalama değerlerinin 21.0-32.0 ml arasında değiştiğini bildirmişlerdir. Bu çalışmadan elde edilen sonuçlar diğer araştırmaların sonuçları ile uyum içindedir. Sedimantasyon değeri bakımından farklılıklar genotipe bağlı olmakla birlikte bu özellik üzerinde iklim faktörlerinin de etkisi bulunmaktadır (Atlı ve ark., 1999). Ayrıca Çağlayan ve Elgün (1999), sedimantasyon değerinin çeşit, çevre ve yetiştirme tekniği yanında süne ve kımıl zararına bağlı olarak da değişebileceğini bildirmişlerdir.

\section{Sonuç}

Araştırma sonucunda; Mardin ve çevresinde ticari olarak yetiştirilen 15 makarnalık buğday çeşidinin incelenen özellikler yönünden varyasyon gösterdiği saptanmıştır. Verim yönünden; Sarıçanak başta olmak üzere Artuklu, Altıntoprak, Güneyyıldızı ve Fırat-93 çeşitlerinin, Hektolitre bakımında Sarıçanak 
ve Eyyubi çeşitlerinin ön plana çıktığı belirlenmiştir. Protein oranı bakımında Zühre çeşidi, Sedimantasyon değeri yönünden Fuatbey çeşidi ön plana çıkmıştır. Çalışma sonucunda, makarnalık buğday çeşitlerinin hem morfolojik hem de teknolojik özellikler bakımından varyasyon gösterdiği ve bu varyasyonunda makarnalık buğday ıslahında çalışan bitki ıslahçıları tarafindan amaçlarına göre kullanılabilecekleri düşünülmektedir.

\section{Kaynaklar}

Akgün İ, Altındal D, Kara B (2011). Isparta ekolojik koşullarında ekmeklik ve makarnalık bazı buğday çeşitlerinin uygun ekim zamanlarının belirlenmesi. Tarım Bilimleri Dergisi - Journal of Agriculural Sciences, 17: 300 - 309. Ankara.

Akman Z, Yılmaz F, Karadoğan T, Çarkçı K (1999). Isparta ekolojik koşullarına uygun yüksek verimli buğday çeşit ve hatlarının belirlenmesi. Türkiye 3. Tarla Bitkileri Kongresi, 15-20 Kasım, 366371. Adana

Aksoy A (2012). Akdeniz İklim Kuşağında Yetiştirilen Bazı Makarnalık Buğday Çeşitlerinin Verim ve Kalite Özelliklerinin İncelenmesi (Basılmamış Yüksek Lisans Tezi) Çukurova Üniversitesi Fen Bilimleri Enstitüsü, Sayfa 48. Adana

Akıncı C, Yıldırım M (2009). F6 Generasyonundaki bazı makarnalık buğday hatlarının verim ve verim unsurlarının karşılaştırılması. Türkiye 8. Tarla Bitkileri Kongresi. 19-22 Ekim 2009 Hatay, 2. Cilt, Sayfa: 423-426.

Anonim (2014). Mardin Meteoroloji Bölge Müdürlüğü Kayıtları. Mardin uzun yıllar ortalaması (19602014), çalışma yıllarına ait sıcaklık, yağış ve nem değerleri http://www.mgm.gov.tr/tahmin/il-veilceler.aspx? $m=$ MARDIN , (03.04.2015)

Atlı A, Koçak N, Aktan B (1993). Ülkemiz çevre koşullarının makarnalık buğday yetiştirmeye uygunluk yönünden değerlendirilmesi. Makarnalık Buğday ve Mamulleri Sempozyumu, 30 Kasım-03 Aralık 1993. Ankara, sayfa, 354-351,

Atlı A, Koçak N, Aktan M (1999). Ülkemiz çevre koşullarının kaliteli makarnalık buğday yetiştirmeye uygunluk yönünden değerlendirilmesi. Orta Anadolu'da Hububat Tarımının Sorunları ve Çözüm Yolları Sempozyumu, 8-11 Haziran, Konya, 498-506.

Ayçiçek M, Yildirim T (2006). Bazı makarnalık buğday (Triticum durum L) çeşitlerinin Erzurum koşullarındaki verim yetenekleri. Fırat Ü. Fen ve Müh. Bil. Dergisi, 18 (2): 151-157.

Aydın N, Tugay E, Sakin MA, Gökmen S (1999). Tokat Kazova koşullarında Makarnalık buğday çeşitlerinin verim ve kalite özelliklerinin belirlenmesi üzerine bir araştırma. Hububat Sempozyumu, 8-11 Haziran 1999, s. 621-625. Konya.

Aydoğan S, Göçmen A A, Şahin M, Demir B, Önmez H, Türköz M, Çeri S (2012). Bazı makarnalık buğday çeşitlerinin kalite özelliklerinin belitlenmesi. Tarla Bitkileri Merkez Araştırma Enst. Dergisi, 21 (1): $1-7$.

Ayoub M, Guertin S, Lussier S, Smith D (1994) Timing and level of nitrogen fertility effects on spring wheat yield in eastern canada. Crop Sci. 34: 748-756.

Blue EN, Mason SC, Sander DH (1990). Influence of planting date, seeding rate and phosphorus rate on wheat yield. Agron. J. 82: 762-768.

Bushuk W (1998). Wheat breeding for end-product use. Euphytica, 100, 137-145.

Budak H, Karaltın S, Budak F (1997). Bazı Ekmeklik Buğday Çeşitlerinin (Triticum aestivum L. Em Thell) Fiziksel ve kimyasal yöntemlerle kalite özelliklerinin belirlenmesi. Türkiye 2. Tarla Bitkileri Kongresi, 22-25 Eylül, Samsun, 534-536.

Çağlayan M, Elgün A (1999). Değişik çevre şartlarında yetiştirilen ekmeklik buğday hat ve çeşitlerinin bazı teknolojik özellikleri üzerinde araştırmalar. Orta Anadolu'da Hububat Tarımının Sorunları ve Çözüm Yolları Sempozyumu, 513-518, 8-11 Haziran, Konya.

Elgün A, Ertugay Z (1995). Tahıl İşleme Teknolojisi. Atatürk Üniversitesi Ziraat Fakültesi, Erzurum.

Genç İ, Yağbasanlar T, Özkan H (1993). Akdeniz iklim kuşağına uygun Makarnalık buğday (Triticum durum desf.) çeşitlerinin belirlenmesi üzerinde araştırmalar. Makarnalık Buğday ve Mamulleri Sempozyumu, s. 127. Ankara.

Gökmen S, Sencar Ö (1989). Tahıl Alanlarında Anız Yakma ve Etkileri. Sivas

Hoseney RC, (1994). Principles of Cereal Science and Technology (2nd ed.). American Association of Cereal Chemists, St. Paul, MN.

Kara R, Dumlupınar Z, Akkaya A, Dokuyucu T (2008). Bazı makarnalık buğday genotiplerinin Kahramanmaraş koşullarında fenolojik dönemler, bazı bitkisel özellikleri ve tane verimi bakımından değerlendirilmesi. KSÜ Fen ve Mühendislik Dergisi, 11(1). 
Kaya M, Şanlı A (2009). Bazı ekmeklik (Triticum aestivum L.) ve makarnalık (Triticum durum L.) buğday çeşitlerinin Isparta ekolojik koşullarında verim ve bazı verim öğelerinin belirlenmesi. Bitkisel Araştırma Dergisi (2009) 2: 27-34.

Kendal E, Tekdal S, Aktaş H, Altıkat A, Karaman M, Baran İ (2011). Diyarbakır ekolojik koşullarına uygun yabancı yazlık Makarnalık Buğday çeşitlerinin belirlenmesi. Uludağ Üniversitesi, Ziraat Fakültesi, Türkiye VIII. Tarla Bitkileri Tarım Kongresi, Cilt 1- sayfa :242-245, 12-25/09.2011 Bursa.

Kılıç H (2003). Güneydoğu Anadolu Bölgesi Koşullarında Makarnalık Buğday Triticum durum L.Çeşitlerinin Bazı Tarımsal ve Kalite Özellikleri ile Stabilitesi Üzerine Araştırmalar. Çukurova Üniversitesi Fen Bilimleri Ens. (Basılmamış Doktora Tezi) 216 s., Adana.

Kılıç H, Dönmez E, Yazar S, Şanal T, Altıkat A (2007). Elazığ ve Malatya Şartlarına uygun makarnalık buğday çeşitlerinin belirlenmesi. Bitkisel Araştırma Dergisi (2007, 2: 6-13.

Kün E (1988). Serin İklim Tahılları. A.Ü. Ziraat Fakültesi Yayınları. No:1032 Ders Kitabı, 299, s. 322, Ankara.

Özberk İ, Özberk F, Coşkun Y (2005). Özberk ve Urfa-2005 makarnalık buğday çeşitlerinin verim performansları ve stabiliteleri. Harran Ü. Ziraat Fak.Dergisi, 9 (3): 29 - 34.

Özkaya H, Özkaya B (1993). Makarnalık kalitesinde buğday bileşiminin önemi. Makarnalık Buğday ve Mamulleri Sempozyumu 30 Kasım-03 Aralık 1993,s:289-296, Ankara.

Sakin M, Yıldırım A, Gökmen S (2004). Tokat Kazova koşullarında bazı makarnalık buğday genotiplerinin verim, verim unsurları ile kalite özelliklerinin belirlenmesi. Tarım Bilimleri Dergisi, 10 (4) 481 - 489.

Tulukcu E, Sade B (2002). Konya Ekolojik Şartlarında Bazı Makarnalık Buğday Genotiplerinin Kuru ve Sulu Şartlardaki Verim Ve Kalite Özelliklerinin Belirlenmesi. Anadolu, J. of AARI 12 (1) 2002, 65 - 82 MARA

TUIK (2014). T.C. Başbakanlık Devlet İstatistik Enstitüsü 2013, http://tuikapp.tuik.gov.tr/bitkiselapp/bitkisel.zul (05.05.2015).

Ünal S (2003). Buğday Un ve Kalitesinin Belirlenmesinde Uygulanan Yöntemler, Nevşehir Ekonomisinin Sorunları ve Çözüm Önerileri. Nevşehir Ekonomisi Sempozyumu, 27-28 Haziran, Nevşehir, 15-29.

Whitman CE, Haffield JL, Reginato RJ (1985). Effect of slope position on the micro climate growth and yield of barley. Agronomy Journal, 77, 663-669. 